洗浄, 硫酸ナトリウムで乾燥後蒸留した。得られた $\gamma$ ーラクトン を $80 \%$ ヒドラジンヒドラートと沸騰湯浴上で 1 時間加熱してヒ ドラジドを得だ。

$\alpha$ ーメチルー 交献 $\mathrm{bp}_{13} 99^{\circ} \sim 100^{\circ} \mathrm{C}$ 甲) ヒドラジト $\mathrm{mp} 127^{\circ} \sim 128^{\circ} \mathrm{C}$ (I ーテルとアルコールから再結晶)。交献 $\mathrm{mp} 124^{\circ} \mathrm{C}$ 》。 分析做 $\mathrm{N} 17.63 \%$

$\mathrm{C}_{7} \mathrm{H}_{16} \mathrm{~N}_{2} \mathrm{O}_{2}$ としての計算值 $\mathrm{N} 17.49 \%$

9) E. E. Blaise, A. Luttringer, Bull. soc. chim. [3] 33, 825 (1905). $\alpha$ ーメチルー $\gamma$-nーノナラクトン 取率 $55 \%$ 。 $\mathrm{bp}_{19} 138^{\circ} \sim 139^{\circ}$ $\mathrm{C}$ 。交献 $\mathrm{bp}_{18} 138^{\circ} \mathrm{C}{ }^{10)}$ 。ヒドラジド $\mathrm{mp} 125^{\circ} \sim 126^{\circ} \mathrm{C}$ (酢 酸エチルから再結晶)。交献 $\mathrm{mp} 116^{\circ} \mathrm{C}$ (6)10)。

\section{分析値 $\mathrm{N} 14.41 \%$}

$\mathrm{C}_{10} \mathrm{H}_{22} \mathrm{~N}_{2} \mathrm{O}_{2}$ としての計算值 $\mathrm{N} 13.85 \%$

終りにのぞみ，本研究にあたり終始御指埒，御触撻を睗わった 東京工業大学大田正樹教授，ならびに元素分析を相当せられた有 機化学教室分析室の方々に深甚の新意を表します。

10) E. E. Blaise, A. Luttringer, ibid. [3], 33, 1102 (1905).

\title{
ナフチルアミンおよびナフチレンジアミンの酸化縮合体の哥蟠性
}

(昭和 37 年 5 月 1 日受理)

$$
\text { 井上博夫·井本 英二十 }
$$

$\alpha$-(または $\beta$-) ナフチルアミン, 1,5-ジアミノナフタリンのそれぞれの二トロベンゼン，無水塩化アルミニゥムによる酸化縮合 反応を種々の条件で榆討した。生成物はいずれの場合も有機溶媒に不浴, 濃硫酸のみに可溶の黒紫色または黒色の不融性粉末であ つた。シメチルホルムアミド可溶成分の紫外；可視四収スペクトルでは約 $300 ， 550 \mathrm{~m} \mu$ 付近に贿収を認めた。また，赤外吸取

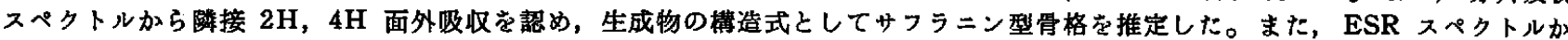

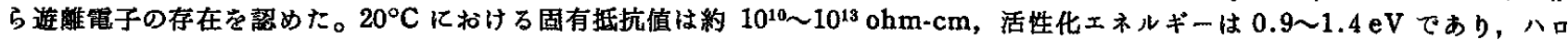
ゲン觉む塩型の高分子化合物はアルカリ処理したものにくらべて，良好な電導性を示した。

\section{1 緒}

導電性高分子化合物のう方，染料を骨格汇有 する高分子化合物の合成注最近多数報告されて いる。たとえば, Epstein らのフタロシアニン の高分子化合物1)，Weiss らのキサンテン型高 分子化合物2などがある。周知のとおり染料は 光伝禉性を有し，すでに Telenin らによって $\mathrm{p}$ 型またはn $\mathrm{n}$ 型の伝導機構をとることも明らか にされているる。著者らは以前から種々の型 の導電性高分子化合物の合成を行なってきた が, 本報告では図 1 に示すように, p 型半導 体として知られているずサフラニン型染料が多 数結合した高分子化合物の合成について検討し た。サフラニン型染料は一般にアニリンや $p$ フェニレンジアミンの酸化によって合成され るす。著者らはこの合成法を利用して，反応し やすいナフタリン環を有する $\alpha$-ナフチルアミ ン, $\beta$-ナフチルアミン,1,5-ジミノナフタリン のそれぞれを，酸化削としてニトロベンゼン， 縮合刘として無水塭化アルミニウムを用いて酸 化䌅合を行なった。この反応の際, ニトロベン ゼンは酸化作用のほかに溶媒としてはたらき，

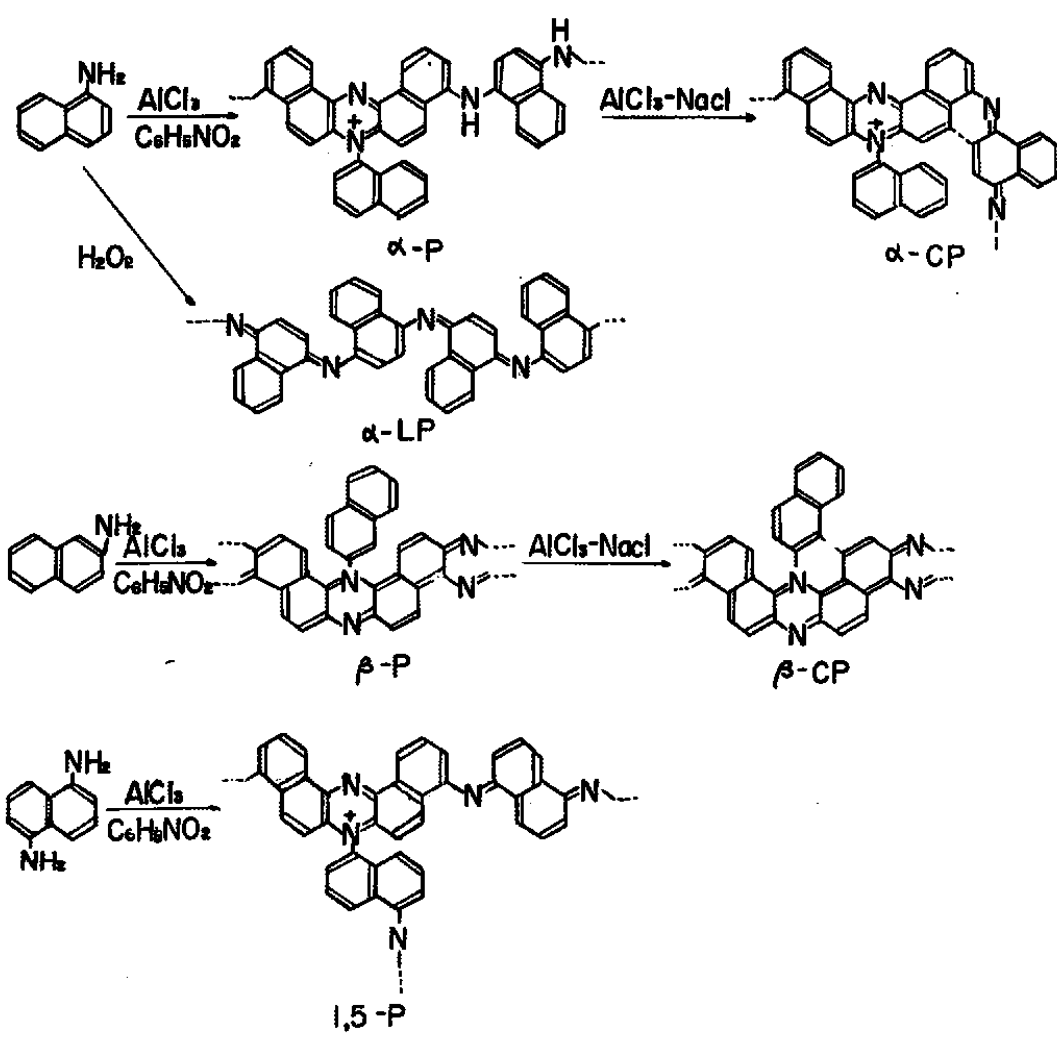

図 1 ナフチルアミンおよびナフチレンシアミンの酸化縮合体の推定構造式
†大服府立大学工学部店用化学教荎, 堺市百舌鳥梅町

1) A. Epstein, J. Chem. Phys. 33, 618 (1960); C. S. Marvel, M. M. Martin, J. Am. Chem. Soc. 88, 6600 (1958).

2) R. McNeill, D. E. Weiss, Aust. J. Chem. 12, 643 (1959).

3) A. Terenin, Proc. Chem. Soc. 1961, 321.

4) P. Barbier, L. Vignon, Bull. soc. chim. France Mem. 48, 338 (1887); o. N. Witt, J. Soc. Chem. Ind. London 1, 255 (1882).
\&た，ニトロベンゼンの遗元生成物はナフチルア・゙ンと同様に酸 化縮合すると考えられる。つぎに，この反応生成物をさらに塭化 アルミニウムー食塭中で溶融し，ナフタリン環同志の縮合を行な わせようとした。以上のようにして，種々の条件で得られた生成 物について導電性を測定し，その結果を比較検討した。 


\section{2 結果と考察}

\section{1 高分子化合物の合成}

$\alpha$-(または $\beta-)$ ナフチルアミンは市販品を, 1,5 -ジアノナフ タリンは 1,5-ジニトロナフタリンを還元して合成し5),いずれる 再結晶によって精憋したものを用いた。表 1，2，3，4 に示した ような種々の条件でニトロベンゼン，無水塩化アルミニウムによ る酸化維合を行なった。 $\alpha$-ナフチルアミンまたは 1,5-ジアるノ ナフタリンはいずれもニトロベンゼンと無水塩化アルミニウムの 伱在下で空温ではげしく発熱反応し, 不融性の黑紫色粉末 $(\alpha-\mathrm{P}$ または 1,5-P と略記する)を与えた。ところが冷却し，4500 にたもちながら徐々に反応させた場合は低融点物質またはタール 状物質が得られるのみであった。 $\beta$-ナフチルアるンの場合は $\alpha-$
ナフチルアミンの場合と同条件下で反応させたが, 発熱反応はみ られず, 温度 $200^{\circ} \mathrm{C}$ で不融性の黑色粉末（ $\beta-\mathrm{P}$ と略記する）が 析出した。不融性粉末の収量は原料のアミンの量よりも堌加した が, 生成物中には分光分析の結果 $\mathrm{Al}^{3+}$ イオンは含まれないので, これは技そらくニトロベンゼンの還元生成物が反応しているため と考党られる。無水塩化アルミニウムをアミン対して約 $1: 1$ （モル比）にとるとき反応はるっとあはげしく，不融性の粉末 が得られた。立た， $\alpha$-ナフチルアミンについて, ニトロベンゼン または無水塩化アルミニウムのいずれかと高温で反応させた場合 は低融点物質しか得られず, 酸化縮合反応にはニトロベンゼンと 無水塩化アルミニウムが同時に必要であるように思われる。アニ リン黑の合成に用いられる過酸化水素-硫酸鉄（I）またはク口 ム酸を酸化削として用いた場合には, いずれも焦茶色の不融性粉

表 1 塩化アルミニウムとニトロベンゼンの影策

\begin{tabular}{|c|c|c|c|c|c|c|c|c|c|c|c|}
\hline \multirow{2}{*}{$\begin{array}{l}\text { 奏験 } \\
\text { 番男 }\end{array}$} & \multirow{2}{*}{$\begin{array}{l}P(\Sigma)(a) \\
(g)^{2}\end{array}$} & \multicolumn{2}{|c|}{ 繀 合 削 } & \multicolumn{2}{|c|}{ 酸 化 浏 } & \multirow{2}{*}{$\frac{\text { 温 }}{\left({ }^{\circ} \mathrm{C}\right)}$} & \multirow{2}{*}{$\begin{array}{l}\text { 時間 } \\
(\mathrm{hr})\end{array}$} & \multicolumn{2}{|r|}{ 生 } & 成 & 物 \\
\hline & & 理 䫓 & (対アネン 比 & 理 類 & (g) & & & 色 & 収 $(\mathrm{g})$ & 醷点 & $\begin{array}{l}\text { ハロ ゲン } \\
\text { 検 出 }\end{array}$ \\
\hline 1b) & 3 & $\mathrm{AlCl}_{3}$ & 1 & - & - & 透流 & 7 & 紫 & 1 & $60 \sim 80$ & + \\
\hline 2 & 3 & $\mathrm{HCl}$ & 1 & $\mathrm{C}_{6} \mathrm{H}_{5} \mathrm{NO}_{2}$ & $12 \sim 14$ & 200 & 9 & 紫 & - & タール状 & + \\
\hline 3 & 3 & $\mathrm{AlCl}_{8}$ & 1 & $\mathrm{C}_{6} \mathrm{H}_{5} \mathrm{NO}_{2}$ & $12 \sim 14$ & $30^{c)}$ & 1 & 黒柴 & $3 \sim 3.5$ & $>\mathbf{3 0 0}$ & + \\
\hline 4 & 6.8 & $\mathrm{HCl}$ & $(13.5 \mathrm{~g})^{d)}$ & $\mathrm{H}_{2} \mathrm{O}_{2}-\mathrm{FeSO}_{4}$ & - & $25 \sim 30$ & 45 & 焦荣 & 3.5 & $>300$ & + \\
\hline $5^{e)}$ & 2 & $\mathrm{HCl}$ & $\therefore-$ & $\mathrm{CrO}_{3}$ & 0.23 & $25 \sim 30$ & 8 & 焦茶 & 1.7 & $>300$ & + \\
\hline
\end{tabular}

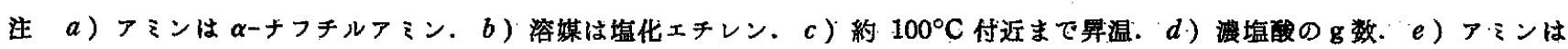
実験番号 4 の生成物と $\alpha$-ナフチルアミン塩酸塩営用いた，f) 分光分析の結果, $\mathrm{Al}^{3+}$ イオンを含まない.

\section{表 2 縮合剤 $\left(\mathrm{AlCl}_{3}\right)$ のモル比（対アミン）の影辐}

\begin{tabular}{|c|c|c|c|c|c|c|c|c|c|}
\hline \multirow{2}{*}{$\begin{array}{l}\text { 実験 } \\
\text { 番号 }\end{array}$} & \multirow{2}{*}{$\begin{array}{c}\left.P \Sigma \sum^{a}\right) \\
(\mathrm{g})\end{array}$} & \multirow{2}{*}{ 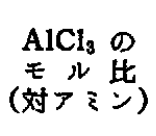 } & \multirow{2}{*}{$\begin{array}{c}\mathrm{C}_{6} \mathrm{H}_{5} \mathrm{NO}_{2} \\
(\mathrm{~g})\end{array}$} & \multirow{2}{*}{$\left({ }^{\circ} \mathrm{C}\right)$} & \multirow{2}{*}{ 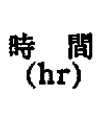 } & \multicolumn{2}{|c|}{ 生 } & \multicolumn{2}{|c|}{ 物 } \\
\hline & & & & & & 色 & 収 $(\mathrm{g})$ & $\left.{ }^{\circ}{ }^{\circ} \mathrm{C}\right)$ & $\begin{array}{l}\text { ハロゲン } \\
\text { 検 }\end{array}$ \\
\hline 6 & 3 & $1 / 30$ & 2.4 & 30 & 18 & 監。 & 0.8 & タール状 & + \\
\hline 7 & 3 & $1 / 6$ & 2.4 & $30 \sim 40$ & 18 & 警 & 0.8 & タール状 & + \\
\hline 8 & 3 & $1 / 3$ & 2.4 & $\left.30 \sim 40^{b}\right)$ & 18 & 濃藍 & - & - & + \\
\hline 9 & 3 & $1 / 1.5$ & 2.4 & $30^{()}$ & 10 & 黒紫 & 2 & $\left.177 \sim 220^{d}\right)$ & + \\
\hline 3 & 3 & 1 & $12 \sim 14$ & $30^{c)}$ & 1 & 黒紫 & $3 \sim 3.5$ & $>300$ & + \\
\hline
\end{tabular}

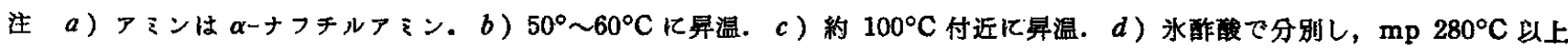
のものな得た（黒紫色粉末）.

\begin{tabular}{|c|c|c|c|c|c|c|c|c|c|c|c|}
\hline \multirow{2}{*}{$\begin{array}{l}\text { 実輸 } \\
\text { 番昼 }\end{array}$} & \multirow{2}{*}{$\begin{array}{c}\gamma_{\bar{\gamma}}(\mathrm{a}) \\
(\mathrm{g})\end{array}$} & \multirow{2}{*}{ 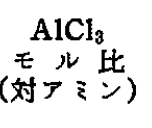 } & \multirow{2}{*}{$\begin{array}{c}\mathrm{C}_{6} \mathrm{H}_{5} \mathrm{NO}_{2} \\
(\mathrm{~g})\end{array}$} & \multicolumn{2}{|c|}{ 第 1 次加熱 } & \multicolumn{2}{|c|}{ 第 2 如加熱 } & \multirow[b]{2}{*}{ 色 } & \multirow{2}{*}{ 収 $(\mathrm{g})^{\text {量 }}$} & \multirow{2}{*}{$\left({ }^{\circ} \mathrm{C}\right)$} & \multirow{2}{*}{$\begin{array}{l}\text { 八ロゲン } \\
\text { 検 }\end{array}$} \\
\hline & & & & $\left(\begin{array}{c}\left.{ }^{\circ} \mathrm{C}\right) \\
\text { 度 }\end{array}\right.$ & $\begin{array}{c}\text { 時 間 } \\
(\mathrm{hr})\end{array}$ & $\left({ }^{\circ} \mathrm{C}\right)^{\text {度 }}$ & $\begin{array}{c}\text { 時 } \text { 間 }^{(h r)} \\
\text { (hen }\end{array}$ & & & & \\
\hline 10 & 3 & 1 & 17 & $0 \sim-10$ & 9 & - & - & 紫 & $0.5 \sim 1$ & $90 \sim 110$ & - \\
\hline 11 & 3 & 1 & 17 & $45 \sim 50$ & 5 & - & - & 黒紫 & 1.5 & $90 \sim 110$ & - \\
\hline 12 & 3 & 1 & 17 & $45 \sim 50$ & 4 & $110 \sim 120$ & 5 & 黒紫 & $3 \sim 3.1$ & $-b$ & + \\
\hline 13 & 3 & 1 & 17 & $30^{c)}$ & 1 & $180 \sim 200$ & 9 & 黒紫 & 3 & $>300$ & + \\
\hline $14^{d)}$ & 3 & 1 & 17 & 30 & 1 & - & - & 累茶 & 一 & $>300$ & - \\
\hline 15 & 3 & 1 & 17 & 30 & 1 & $\left.130 \sim 140^{e}\right)$ & 20 & 黑茶 & 一 & $>300$ & + \\
\hline 16 & 3 & 1 & 17 & 30 & 1 & $\left.110 \sim 120^{e}\right)$ & 20 & 黑 & - & $>300$ & + \\
\hline 17 & 3 & $1 / 3$ & 2.4 & 30 & 18 & $200^{e)}$ & 1 & 黒 & - & $>300$ & + \\
\hline
\end{tabular}

注 a) アミンは $\alpha$-ナフチルアミン.

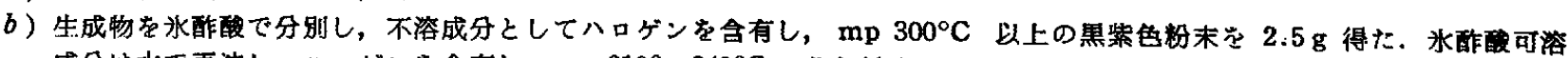 成分は水で再沈し，八ロゲンき含有し，mp $210^{\circ} \sim 240^{\circ} \mathrm{C}$ の藍色粉末約 $0.2 \mathrm{~g}$ 得た。
c) 約 $100^{\circ} \mathrm{C}$ k昇温.
d) 生成物觉 $10 \%$ 水酸化ナトリウムーエタノール水中で 6 時間加熱した。
$e)$ 第 1 如加熱で得た生成物をとり出し, $\mathrm{AlCl}_{3} \mathrm{NaCl}(5: 2$ の重量比) 中で溶融した. 
表 4 ア ミンの種 類によえ影總

\begin{tabular}{|c|c|c|c|c|c|c|c|c|c|c|c|c|}
\hline \multirow{2}{*}{$\begin{array}{l}\text { 実跧 } \\
\text { 番号 }\end{array}$} & \multicolumn{2}{|c|}{$\boldsymbol{r}$ ₹ ン } & \multirow{2}{*}{$\begin{array}{c}\mathrm{AlCl}_{3} \\
₹ ル \text { 比 } \\
\text { (奶アミン) }\end{array}$} & \multirow{2}{*}{$\begin{array}{c}\mathrm{C}_{6} \mathrm{H}_{5} \mathrm{NO}_{2} \\
(\mathrm{~g})\end{array}$} & \multicolumn{2}{|c|}{ 第 1 次加熱 } & \multicolumn{2}{|c|}{ 第 2 次加熱 } & \multicolumn{2}{|r|}{ 生 } & 成 & \multirow{2}{*}{$\frac{\text { 物 }}{\text { 八ロゲン }}$} \\
\hline & 種類 & (g) & & & $\stackrel{\left({ }^{\circ} \mathrm{C}\right)}{\text { 度 }}$ & $\begin{array}{c}\text { 時 間 } \\
(\mathrm{hr})\end{array}$ & ${ }^{\circ}$ 温 $\left.\mathrm{C}\right)$ & 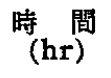 & 色 & 收 $(\mathrm{g})$ & $\left({ }^{\circ} \mathrm{C}\right)$ & \\
\hline $18^{a)}$ & $\beta-$ & 3 & 1 & $12 \sim 14$ & $180 \sim 200$ & 1.5 & - & - & 黒 & $3.5 \sim 4$ & $>300$ & - \\
\hline 19 & $\beta-$ & 3 & 1 & $12 \sim 14$ & $180 \sim 200$ & 1.5 & 200 & $3.5^{a)}$ & 黒 & 3 & $>300$ & + \\
\hline 20 & $1.5-$ & 1 & 1 & 20 & $\left.30^{c}\right)$ & 0.5 & 150 & 4 & 黒 & $1.2 \sim 1.5$ & $>300$ & + \\
\hline $21^{d)}$ & $\alpha-$ & 3 & 3 & $12 \sim 14$ & $\left.30^{c}\right)$ & 5 & - & - & 黒紫 & 1 & $>300$ & + \\
\hline
\end{tabular}

注 $a)$ 生成物を $10 \%$ 水酸化ナトリウムーエタノール水中で 6 時間加熱した.

b) $\mathrm{AlCl}_{8}-\mathrm{NaCl}$ 中で熔融反灾. c) 約 $100^{\circ} \mathrm{C}$ 付近に舁温. $d$ ) 公素気流中で反応させた.

\begin{tabular}{|c|c|c|c|c|c|c|c|c|c|c|c|c|c|}
\hline & & 溶 & 解 & 䒜 & a) & & & 元 & 素 & 析 & 值 & & \\
\hline 料 & $\begin{array}{l}\text { アセ } \\
\text { トン }\end{array}$ & $\begin{array}{l}ク ロ \square \\
\text { ホルム }\end{array}$ & 水酢 & $\mathrm{DMF}^{()}$ & 濃硫酸 & & C & $\mathrm{H}$ & $\mathbf{N}$ & $\mathrm{Cl}$ & $\mathbf{O}$ & 灰分 & 実＼cjkstart験 \\
\hline$\alpha-P-11$ & $H$ & H & $H$ & W & 冊 & 青 & - & - & 一 & 0 & 一 & - & - \\
\hline$\alpha-P-12^{b)}$ & + & + & + & H & 册 & 緑 & - & - & - & 1.55 & - & 一 & - \\
\hline$\alpha-P-3^{d)}$ & - & - . & - & $H$ & 册 & 緑青 & 76.68 & 4.73 & 7.10 & 13.8 & 0 & 0 & $\mathrm{C}_{99} \mathrm{H}_{25} \mathrm{~N}_{3} \mathrm{Cl}_{2}$ \\
\hline$\alpha-C P-15$ & - & - & - & - & + & 黑青 & 76.93 & 4.40 & 6.77 & 4.40 & 5.83 & 3.1 & $\mathrm{C}_{39.8} \mathrm{H}_{27.5} \mathrm{~N}_{3} \mathrm{Cl}_{0.8} \mathrm{O}_{2.2}$ \\
\hline$\alpha-\mathrm{P}-13$ & - & - & - & H & 册 & 緑青 & 76.97 & 4.50 & 8.95 & 2.34 & 5.25 & 3.69 & $\mathrm{C}_{40} \mathrm{H}_{28} \mathrm{~N}_{4} \mathrm{Cl}_{0.4} \mathrm{O}_{2}$ \\
\hline$\alpha-P-21$ & - & - & $H$ & 册 & 册 & 緑青 & 77.61 & 4.84 & 8.77 & 1.98 & 4.81 & 3.69 & $\mathrm{C}_{41} \mathrm{H}_{30.7} \mathrm{~N}_{4} \mathrm{Cl}_{0.2} \mathrm{O}_{1.8}$ \\
\hline$\alpha-\mathrm{LP}=4$ & $H$ & $H$ & $H$ & 册 & 典 & 黒緑 & - & - & - & 3.46 & 一 & - & - \\
\hline$\beta-P-18$ & + & + & + & 册 & 册 & 藍 & 74.02 & 4.74 & 12.84 & 1.21 & 4.08 & 5.76 & $\mathrm{C}_{82.4} \mathrm{H}_{24.3} \mathrm{~N}_{4} \mathrm{O}_{1.2}$ \\
\hline$\beta-\mathrm{CP}-19$ & - & - & - & - & H & 緑 & 77.46 & 4.72 & 7.82 & 5.65 & 0.75 & 6.0 & $\mathrm{C}_{45.6} \mathrm{H}_{33.7} \mathrm{~N}_{4} \mathrm{Cl}_{1.2}$ \\
\hline $1,5-P-20$ & - & - & - & + & 曲 & 黒紫 & - & - & - & 3.94 & - & - & - \\
\hline
\end{tabular}

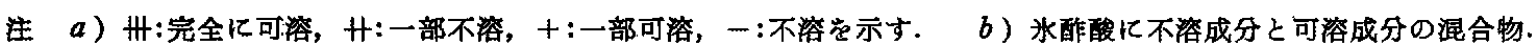

c) シメチルホルムアミドの略記. $\quad d$ ) 分光分析の結果, $\mathrm{Al}^{3+}$ は $10^{-2} \sim 10^{-3} \mathrm{wt} \%$ 以下で $\mathrm{Al}^{3+}$ 苍含まないとみなす.

末（ $\alpha$-LP と略記する）が得られた。以上のようにして得られた 不融性粉末 $\alpha-P, \beta-P$ Kついて, 無水塭化アル 中で溶融反応を試みた。その結果, 反応時間が約 $2 \sim 3$ 時間ぐら いで反応物は固化するが, さらに加熱をつゔけると生成物は黒色 の不融性粉末（ $\alpha-\mathrm{CP}, \beta-\mathrm{CP}$ と略記する）となった。 $\alpha-P$, $\beta-P ， 1,5-P$ は表 5*1 に示すようにいずれも濃硫酸に溶解し，ほ とえどの有機溶媒に不溶性であるが， $\boldsymbol{\alpha}$-LP 注氷酢酸に可溶であ った。アニリン黒の合成の際の中間体であるエメラルジン型のも の（Ｉ）は氷酢酸に可溶であるが6)，サフラニン型のアニリン黑 は承酢酸に不溶性となるので, $\alpha$-LP はエメラルシン型の構造式 をるつように思われる。

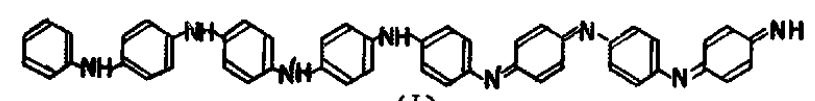

(I)

また, サフラニン型染料は $p \mathrm{H}$ の大小により変色し, 濃唡酸中 では緑青色を呈するつが， $\alpha-P, \beta-P, 1,5-P$ なども濃硫酸中サ フラニン型染料に類似した呈色を示した（表 5)。また，ジメチ ルホルムアミドに可溶性の高分子化合物について, 紫外, 可視吸 匢スペクトルを測定した結果， $\alpha-\mathrm{P} ， \beta-\mathrm{P}$ はいずれも $300 ， 550$

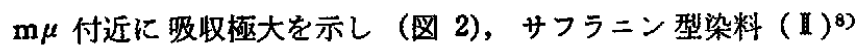
またはフルオリシン (四) でみられるような昅取波長をむち， $\alpha$-LP の場合は $\alpha-P, \beta-P$ などにくらべて短波長すなわ方 480 $\mathrm{m} \mu$ 付近に吸取を示した。赤外吸取スペクトルからは表 6 のよう

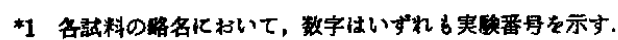

6) A. G. Green, A. E. Woodhead, J. Chem. Soc. 101, 1117 (1912).

7) F. Kehrmann, R. Speitel, E. Grandmougin, Ber. 47, 3205 (1914).

8) G. N. Lewis, J. Am. Chem. Soc. 87,770 (1945).

9) G. M. Badger, R. Pettit, J. Chem. Soc. 1051, 3213.

に， $\alpha-\mathrm{P}, \beta-\mathrm{P}$ いずれの場合も $2 \mathrm{H}, 4 \mathrm{H}$ 隣接面外吸收が認めら れ， $\alpha$-ナフチルア ₹ンの $3 \mathrm{H}$ 面外吸取, $\beta$-ナフチルアミンの 1 H 面外吸収は認められなかった。すなわち縮合はおもにナフタ リン環の 1,2 位, 5,6 位でおこっているように思われる。また， 吸取曲線は $\alpha$-ナフチルアミンをヨウ素で酸化したサフラニン型 化合物 ${ }^{10}$ の赤外吸取スペクトルともほとんど一致した。 $\alpha$-LP の 赤外吸取スペクトルからもをた $2 \mathrm{H}, 4 \mathrm{H}$ の瞵接面外吸取を認め

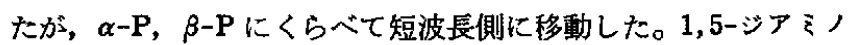
ナフタリンの場合は $2 \mathrm{H}, 3 \mathrm{H}$ 隣接面外吸收を認めた。つぎに, 不融性高分子化合物の元繁分析值とこの值から得られる実験式は 表 5 のようになった。紫外, 可視, 赤外吸取スペクトルの結果や 文献記載の関連化合物の合成条件などを考え合わせると $\alpha-P, \beta-$ $\mathrm{P}$ に対して図1のような構造式が推定される。 $\alpha-\mathrm{CP}, \beta-\mathrm{CP}$ は いずれむ $\alpha-\mathrm{P}, \beta-\mathrm{P}$ にくらべて単位構造式中の炭素, 窒素の数 が増加し，また， $\alpha-P-13 * 2$ は酸素の数が増加しており，かなり 複雑な反応がおこっているように思われる。

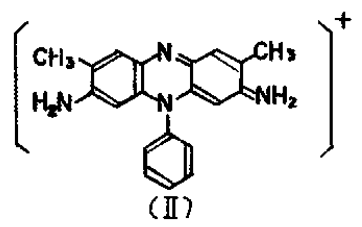

以上のようにして得られた諸種の高分子化合物のうち， $\alpha-\mathrm{P}-3$, $\alpha-\mathrm{CP}-15, \beta-P-18$ について, つぎに ESR スペクトルを調べた。 その結果, いずれも $\alpha-P-3$ (図 3) に類似した吸取曲線を示し, 遊離電子が存在することを認めた。スピン濃度（表 7) 性試精の

*2 酸菜数が多いのはオキ甘シン謤が一部生成されているためと考えられる。

10) H. H. Hodgson, E. Marsden, J. Chem. Soc. 1938, 1181. 
表 6 赤外吸収スペクトルの眀収带

\begin{tabular}{|c|c|c|c|c|c|c|c|}
\hline & & & 収 & 带 & $\left.\left(\mathrm{cm}^{-1}\right)^{a}\right)$ & & \\
\hline 試 料 & $i_{1}^{+N}$ & $-\mathrm{C}=\mathrm{N}-$ & $-\mathrm{C}=\mathrm{C}-$ & & & & \\
\hline$\alpha-\mathrm{P}-11$ & - & 1625 & 1585,1520 & - & 825 & 790 & 770 \\
\hline$\alpha-\mathrm{P}-12$ & - & 1615 & 1580,1520 & 一 & $815 \sim 825$ & $(805)^{b)}$ & 760 \\
\hline$\alpha-\mathrm{P}-3$ & 2780,2580 & 1620 & 1585,1515 & - & 830 & $(805)^{b)}$ & 760 \\
\hline$\alpha-\mathrm{P}-14$ & - & 1620 & $1570,-$ & 一 & $840 \sim 850$ & $(800)^{b)}$ & 760 \\
\hline$\underset{(\mathrm{HCl})}{\left.\alpha-\mathrm{P}-14^{c}\right)}$ & $2800 \sim 2600$ & 1620 & $1590,1540,1505$ & 一 & \multicolumn{2}{|c|}{$825 \sim 800$} & 755 \\
\hline$\alpha-\mathrm{CP}-15$ & 一 & 1620 & $1500 \sim 1600$ & - & \multicolumn{2}{|c|}{$825 \sim 800$} & $750 \sim 760$ \\
\hline$\alpha-\mathrm{P}-21$ & - & 1625 & $1590,1545,1515$ & 一 & 825 & - & 760 \\
\hline$\alpha-\mathrm{LP}-4$ & - & & $1670 \sim 1580$ & - & 845 & 一 & 765 \\
\hline$\beta-P-18$ & $(2900)$ & 1625 & 1595,1500 & - & 815 & - & 745 \\
\hline$\beta-\mathrm{CP}-19$ & - & 1625 & 1585,1515 & - & $820 \sim 830$ & - & $760 \sim 765$ \\
\hline $1,5-P-20$ & - & & $1625 \sim 1500$ & - & 805 & $750 \sim 760$ & - \\
\hline
\end{tabular}

注 $a$ ）打むな吸収带のみを記した。

$b$ ）明取は非常に弱い. $\quad c$ ） $\alpha-P-14$ 岂塩酸越理したもの.

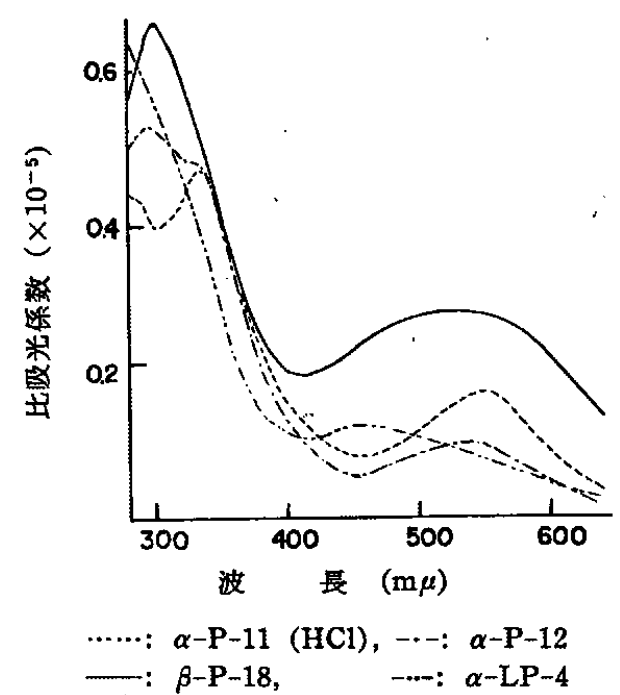

园 $2 \alpha-\mathrm{P}-11(\mathrm{HCl}), \alpha-\mathrm{P}-12, \beta-\mathrm{P}-18, \alpha-\mathrm{LP}-4$ の紫外, 可視吸取スペクトル

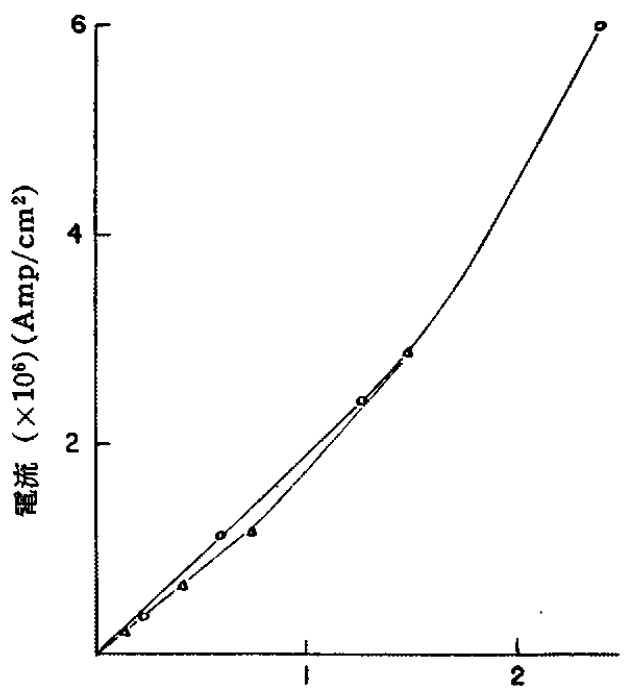

電圧 $\left(\times 10^{-4}\right)(\mathrm{V} / \mathrm{cm})$

$-\mathrm{O}-\mathrm{x} \alpha-\mathrm{P}-3,-\triangle-\mathrm{-}, 1,5-\mathrm{P}-20$

図 $3 \alpha-\mathrm{P}-3,1,5-\mathrm{P}-20$ の電圧特性
轵類によってほとんど差はなく，いずれむポリアクリロニトリル の熱分解生成物のスピン濃度いに類似した值であった。

\section{2 等整性}

電気抵抗は既報12》の方法にしたがって，1〜3 mmHg の減圧 下, $1000 \sim 1250 \mathrm{~kg} / \mathrm{cm}^{2}$ の圧力で压縮しながら測定した。まず， $\alpha-P-3,1,5-P-20$ について電圧特性を測定した結果, 図 4 に示 すように，オーム則が成立することを認めた。したがって，いず れの高分子化合物も $2000 \mathrm{Volt} / \mathrm{cm}$ 以下で測定を行なった。固有 抵抗值の対数と $1 / T$ との関係を試料 $\alpha-\mathrm{P}-3,1,5-\mathrm{P}-20, \alpha-\mathrm{CP}-$

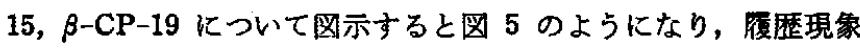
はみられなかった。図 5 以外の試料についても同様であった。ま た， $\alpha-\mathbf{P}-3$ について，室温で 7 日間電流の時間依存性を謂べた が全然変化はみられなかった。 $\log \rho$ と $1 / T$ 之の関係から, 次 式にしたがって $\Delta \varepsilon$ を計算した。 $\rho_{20}$ と $\Delta \varepsilon$ との值は表 7 のよ になり, 合成条件, 性状から比較的低分子量と思われる商分子化

$$
\rho=\rho_{0} \exp \left(\frac{\Delta \varepsilon}{2 k T}\right)
$$

合物はいずれる $\rho_{20}, \Delta \varepsilon$ は大きく，一方不融，不溶性高分子化合 物は $\rho_{20}, \Delta \varepsilon$ の值は小さいことがわかる。 $\alpha-\mathrm{P}, \beta-\mathrm{P}(\mathrm{HCl}) * 8,1,5-$ $P$ の種類によって電導性に差はなく，いずれの場合も大体 $10^{\circ}$

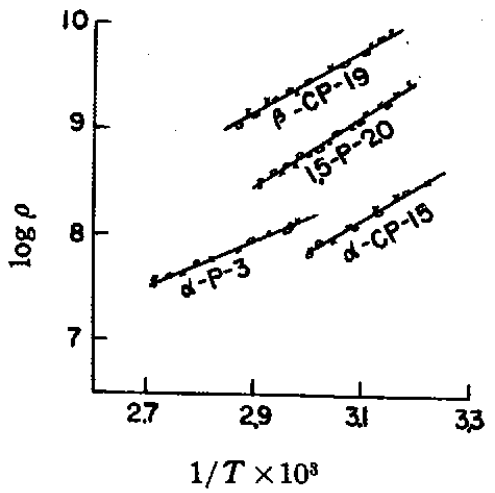

図 $4 \alpha-\mathrm{P}-3, \alpha-\mathrm{CP}-15, \beta-\mathrm{CP}-19,1,5-\mathrm{P}-20$ の $\log \rho$.と $1 / T$ との堅俰

11) A. V. Topchiev, M. A. Geiderikh, B. E. Davydov, V. A. Kargin, B. A. Krentsel, I. M. Kustanovich, L. S. Polak, Doklady Akad. Nauk S. S. S. R. 128312 (1959).

12）井上，港内，井本，工化 85,10号措载革定 (1962).

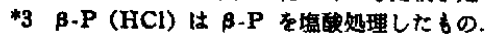




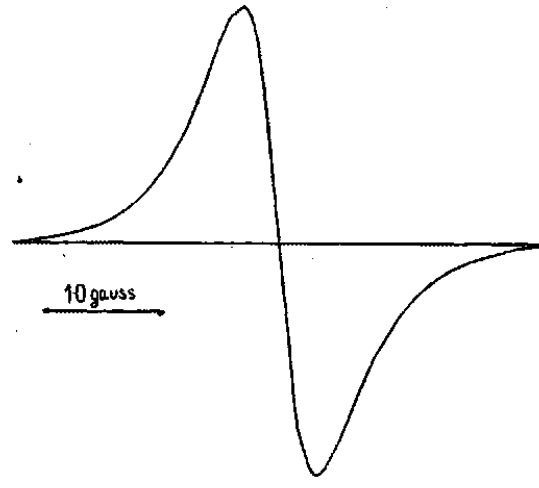

圀 $5 \alpha-P-3$ のSR スペクトル

$10^{10} \mathrm{ohm}-\mathrm{cm}, 1.2 \sim 1.3 \mathrm{eV}$ の值を示した。また， $\alpha-\mathrm{CP}, \beta-\mathrm{CP}$ はいずにも $\alpha-P, \beta-P$ にくらべて $\Delta \varepsilon$ は小さい。これはおねら く溶融反応において環同志の縮合反応がおこっているためと思わ れる。また， $\alpha$-LPの $\rho_{20}, \Delta \varepsilon$ が低分子化合物 $\alpha-P-11$ よりも 大きいのは $\alpha$-LP の敝造式がェメラルジン型であるためと思わ れる。一般的傾向として，ハロゲン含有量の大きい塩型の高分子 化合物は電導性が良好である。たとえば，アルカリ処理した高分 子化合物 $\alpha-P-11, \alpha-P-12(S), \alpha-P-14, \beta-P-18$,などはいずれる $\rho_{20}, \Delta \varepsilon$ が大きいが，これらの高分子化合物を酸処理すると電導 性は良好になり， $\rho_{20}, \Delta \varepsilon$ の值はアルカリ処理する前の值に近く なることがわかる。アジン型染料の可視吸収スペクトルは 550 $\mathrm{m} \mu$ 付近の特性吸收が $\mathrm{pH}$ の大小により異なり， $\mathrm{pH}$ が小さく なるほど長波長側に移動する8)ことから考えて, 上記のサフラ二 ン型高分子化合物もハロゲンを含有するものはつぎのような正電 荷による共鳴棈造 (V)，(V)，(汭)があり，このために励起エネ

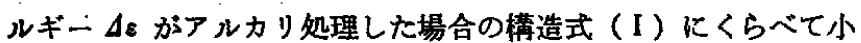
さくなると思われる。また， $\log \rho_{0}$ と $\Delta \varepsilon$ との間には図6のよ うな值線関係があり，化合物の種類により 2 個の直線, すなわち 不融，不溶性の塩型化合物 (A) 群とハロゲンを含まない低分子 化合物またはアルカリ处理した化合物（B）群にわかれる。塭型 の化合物はB 群に属する化合物に比较して $\log \rho_{0}$ が小さいこと がわかる。以上のように, 程型化合物は $\Delta \varepsilon, \rho_{0}$ が小さく電導性 は良好であった。

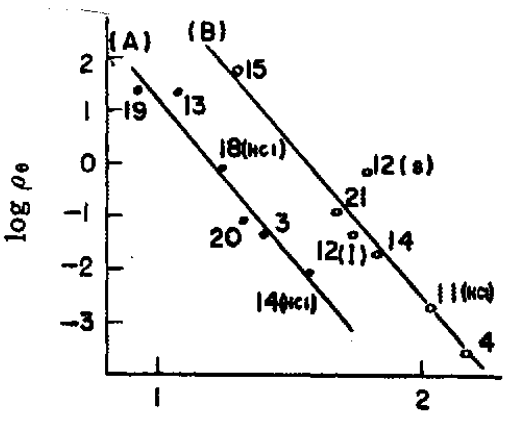

$\Delta \varepsilon(\mathrm{eV})$

図中の数字は试料の略名の数字（夷蛤番号）宗す

図 $6 \log \rho_{0}$ と $\rfloor \varepsilon$ との関係

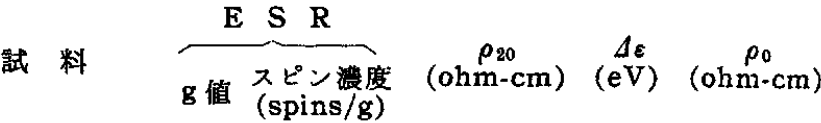

$\begin{array}{llllll}\alpha-\mathrm{P}-11 & - & - & 10^{17 \sim 18} \quad-\end{array}$

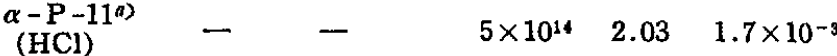

$\begin{array}{llllll}\left.\alpha-\mathrm{P}-12^{b}\right) & - & - & 1.5 \times 10^{15} & 1.78 & 7.1 \times 10^{-1}\end{array}$

$\begin{array}{llllll}\alpha-\mathrm{P}-12^{b)} & - & - & 3.7 \times 10^{13} & 1.73 & 4.7 \times 10^{-2}\end{array}$

$\begin{array}{llllll}\alpha-P-3 & 2.0031 & 5 \times 10^{18} & 4.9 \times 10^{10} & 1.40 & 4.3 \times 10^{-2}\end{array}$

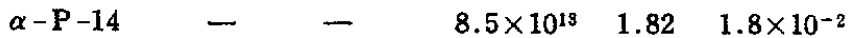

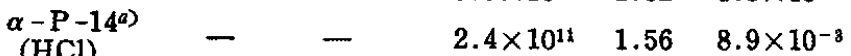

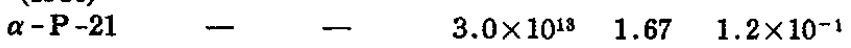

$\begin{array}{llllll}\alpha-\mathrm{CP}-15 & 2.0033 & 1 \times 10^{19} & 6.9 \times 10^{12} & 1.29 & 5.4 \times 10\end{array}$

$\begin{array}{llllll}\alpha-\mathrm{CP}-13 \quad-\quad & - & 3.5 \times 10^{10} & 1.07 & 2.1 \times 10\end{array}$

$\begin{array}{llllll}\alpha-\mathrm{LP}-4 & - & - & 1.0 \times 10^{15} & 2.16 & 2.5 \times 10^{-4}\end{array}$

$\alpha-L P-5 \quad-\quad-\quad\left(3 \times 10^{12}\right)^{c)} \quad-\quad-$

$\begin{array}{llllll}\beta-P-18 & 2.0036 & 7 \times 10^{18} & >10^{15} \quad- & -\end{array}$

$\begin{array}{llllll}\left.\beta-\mathrm{P}-18^{a}\right) & - & - & 3.7 \times 10^{10} & 1.24 & 7.8 \times 10^{-1}\end{array}$

$\begin{array}{llllll}\beta-\mathrm{CP}-19 \quad-\quad & - & 1.5 \times 10^{9} & 0.91 & 2.2 \times 10\end{array}$

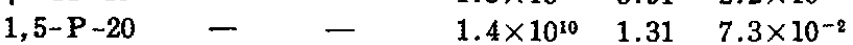

注 $\quad a)$ 㙁酸処理したもの.

b) $\alpha-\mathrm{P}-12$ (S)， $\alpha-\mathrm{P}-12$ (I) 岋それぞれ氷酰酸に可溶, 不 溶成分.

c) 温度 $60^{\circ} \mathrm{C}$ の倠.

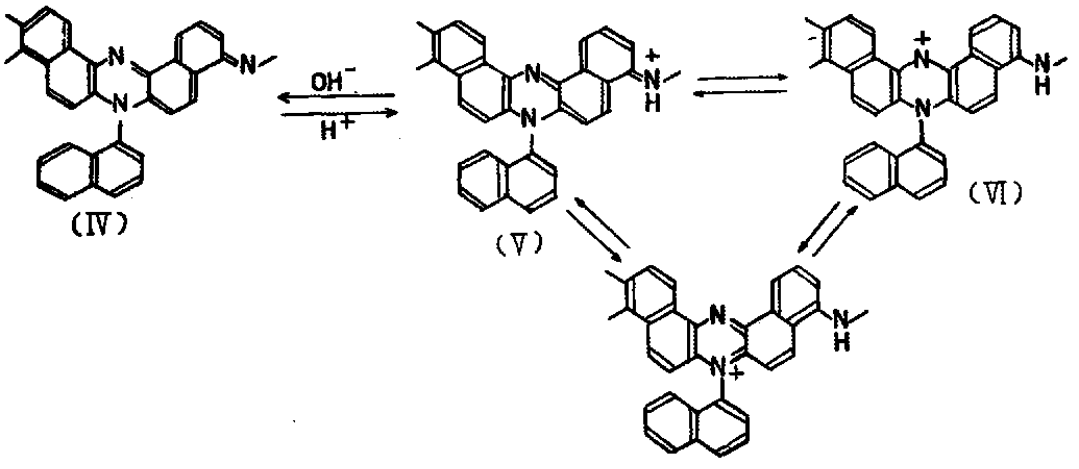

(VII)

塩化アルミニウム $3 \mathrm{~g}$ の混合物中に, ニトロベ ンゼン $15 \mathrm{cc}$ を窒素気流下，室温でかきまぜな がら徐々に滴下した。的 $5 \mathrm{cc}$ 滴下したとき, 白煙を発しはげしく反応した。滴下後, 窒素気 流下で約 5 時間がきぜをつゔけたのち， 1 夜 放置した。反忘混合物中に氷片を添加し，約 2 㭙間かきまぜ，捁化アルミニウムを分解した。 二層に分離したニトロベンゼン層をわけ，ベン ゼン約 $50 \mathrm{cc}$ 它添加して放置した。析出する黒 紫色沈殿をすばやく口過，約 $30 \mathrm{cc}$ のベンゼン で洗浄をくり返した。つぎに，この沈殿を約 50

\section{3 実 臥 の 部}

3.1 a-ナフチルアミン-ニトロベンゼン・塭化アルミニウムの 反店

3.1 .1 窒素舟流中, 荎温で反応: $\alpha$-ナフチルアミン $3 \mathrm{~g}$, 無水 cc の蒸留水中に添加し， $80^{\circ} \mathrm{C}$ ，窒素気流下でかきまぜた。口過 後, 口液中にアンモニア水を添加しても白濁しなくなるまで蒸留 水による洗浄操作をくり返した*4。以上のようにして得た黒紫色 粉末を窒素気流 $10 \mathrm{~mm} \mathrm{Hg}$ 減圧下, 五酸化リン上, $50^{\circ} \mathrm{C}$ で乾燥し 
た。不蛽性黑柴色粉末約 $1 \mathrm{~g}$ を得た。

3.1 .2 空気中, 空温で反応: $\alpha$-ナフチルアミン $3 \mathrm{~g}$, 塩化アル 乏ニウム $3 \mathrm{~g}$ の混合物中に, ニトロベンゼン約 $10 \mathrm{cc}$ を添加し た。はげしく白煙を発しながら橓間的に反応し固化した。1 夜放 犆したのち，反応物を氷中に投入し，水層を分嚁したのち水蒸気 蒸留によりニトロベンゼンを留去し, 残留物の沈殿を熱時に口過 した。つぎに $100 \mathrm{cc}$ 蒸留水中での煮沸完，口液がアンモニア水 によって白濁しなくなるまで行なった。沈殿をエタノール，エー テルで洗浄後, 3.1 .1 の場合と同じ要領で乾燥し, 不融性柴色粉 末約 $3.5 \mathrm{~g}$ を得た。

3.1 .3 第 2 次加熱の場合: 無水塩化アルミニウム $3 \mathrm{~g}$ を二トロ ベンゼン $10 \mathrm{cc}$ 中に溶かした溶液中に， $\alpha$ ーナフチルアミン $3 \mathrm{~g}$ ニトロベンゼン $5 \mathrm{cc}$ 中に溶かした液を, 温度 $45^{\circ} \sim 50^{\circ} \mathrm{C}$ でか きまぜながら徐々に滴下した。滴下後， $45^{\circ} \sim 50^{\circ} \mathrm{C}$ で約 4 時間か きまぜたのち，徐々に $110^{\circ} \sim 120^{\circ} \mathrm{C}$ に䒜温しさらに約 5 時間か きまぜた。反応容器の器壁にコロイド状の沈殿が析出した。反応 物を承中に添加し，3.1.2 の場合と同様に後処理した。得られた 沈殿を承酢酸 $20 \mathrm{cc}$ 中に添加し, 不溶性成分として, mp $300^{\circ} \mathrm{C}$ 以上の黒紫色粉本を約 $2.5 \mathrm{~g}$ 得た。一方, 水酢酸中には水を添加 しバイルスタイン試験陰性の $\mathrm{mp} 210^{\circ} \sim 240^{\circ} \mathrm{C}$ の䒸色粉末を 的 $0.2 \sim 0.3 \mathrm{~g}$ 得た。

3.1 .4 反応温度 $0^{\circ} \sim-10^{\circ} \mathrm{C}$ の坦合: 3.1 .3 の場合と同様にし て,温度 $0^{\circ} \sim-10^{\circ} \mathrm{C} て ゙ 9$ 時間反応させた。反応物中にはコロ ド状沈殿はみられなかった。水蒸気蒸留ののち, 残留物としてゴ ム状物質を得た。冷却すると固化した。3.1.2 の場合と同様に後 処理し, $\mathrm{mp} 90^{\circ} \sim 110^{\circ} \mathrm{C}$ の黑紫色粉末を $0.5 \sim 1 \mathrm{~g}$ 得た。

\section{2 無水堨化アルミニゥムー食塩による溶繦反応}

a-CP-15 の咺合: $5 \mathrm{~g}$ の無水塩化アルミニウムと $2 \mathrm{~g}$ の食塩を 混合し, 温度約 $100^{\circ} \sim 110^{\circ} \mathrm{C}$ で溶融させたのち，かきまぜなが ら $\alpha-\mathrm{P}-3$ の $1 \mathrm{~g}$ を徐々に添加した。塩酸ガスを発生しながら, $\alpha-\mathrm{P}-3$ は溶融した。添加終了後, 約 1〜2 時間かきまぜをつづけ ると内容物は固化しはじめる。さらに, 約 5 時間同温度で加熱を つづけ, 内容物を完全に固化させたのち, 氷を添加して熄化アル ミニウムを分解した。口過後, 得られた黒色の固形物を乳バチで 粉砕し, 3.1.2 の場合と同様にして精裂, 乾燥し, 不融, 不溶性 の黑色粉末を得た。

\section{3 塩酸またはアルカリ処理}

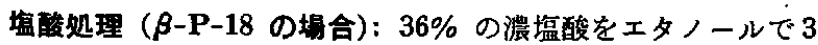
倍に希釈した液 $10 \mathrm{cc}$ 中に, $0.7 \mathrm{~g} の \beta-\mathrm{P}-18$ を添加し, 約 8 時 間放置した。可後, 蒸留水, エタノールで洗浄して, $10 \mathrm{mmHg}$
減压下, 五酸化リン上, 室温で 5 時閏乾燥した。黒色の不融性粉 末 $0.6 \mathrm{~g}$ を得た。

アルカリ処理 ( $\alpha-\mathbf{P}-3$ の娪合)： $\alpha-P-3$ の $1 \mathrm{~g}$ を 10\% 水酸化 カリウムエタノール水 $50 \mathrm{cc}$ 中に添加し, 的 8 時間還流した。冷 却, 口過後, エタノール, 水で洗浄, 乾燥した。ハロゲンのパイ ルスタイン試験陰性の黑色粉末約 $0.9 \mathrm{~g}$ を得た。その他の試料に ついてむ, 同じ要領で程酸処理またはアルカリ好理した。

$3.4 \beta$-ナフチルアミンーニトロベンゼン・塩化アルミニウムの 反応

$3 \mathrm{~g}$ 無水程化アルミニウムを $10 \mathrm{cc}$ のニトロベンゼンに溶かし た液を， $3 \mathrm{~g}$ の $\beta$-ナフチルアミンをニトロベンゼン約 $5 \mathrm{cc}$ 中に 溶かした液中に室溻で徐々に添加した。液は黒紫色に变化したが

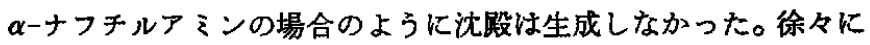
昇温し, 約 $180^{\circ} \sim 200^{\circ} \mathrm{C}$ 付近にするとはげしく反応し, 反応液 は完全に固化した。約 1 時間半同温度で加熱をつつけたのち, 内 容物を氷中に添加して塭化アルミニウムを分解した。水層を分䜅 したのち, 水蒸気蒸留によりニトロベンゼンを留去し, 残留物を 熱時口過した。得られた黑色粉末を $\alpha$-ナフチルアミンの場合と 同様に精製，乾燥し，黒色不融性粉末約 $3.5 \mathrm{~g}$ を得た。

$3.5 \alpha$-ナフチルアミン-過酸化水羕・硫破鉄(II)-クロム限の反 度

$6.8 \mathrm{~g}$ の $\alpha$-ナフチルアミンを水 $200 \mathrm{cc}$ に分散させた液中に, $13.5 \mathrm{~g}$ の蕽塩酸, $38 \mathrm{cc}$ の $5 \%$ 過酸化水素, $0.9 \mathrm{~g}$ の硫酸鉄 (I) の混合物を温度 $0^{\circ} \mathrm{C}$ でかきまぜながら徐々に滴下した。さらに， $0^{\circ} \mathrm{C}$ で 1 時間, 室温で 44 時間かきまぜると反応物俚次第に黒褐 色また黒色に変化した。口過し, 水 $100 \mathrm{cc}$ で洗浄後, さらに 沈段を約 $20 \mathrm{cc}$ の浱アンモニア水中に添加，約 1 時間かきまぜ た。ロ過後, アンモニアの真いがなくなるまで水で洗浄, $10 \mathrm{~mm}$ $\mathrm{Hg}$ 隇圧下, 五酸化リン上, $50^{\circ} \mathrm{C} て ゙$ 乾燥した。焦茶色の不融性 粉末約 $3.5 \mathrm{~g}$ を得た。

クロム酸酸化: 過酸化水素酸化で得られた生成物 $2 \mathrm{~g}, \alpha$-ナフ チルアミン塭酸塩 $1.3 \mathrm{~g}$ を $30 \mathrm{cc}$.の水中に分散させた液中に, $0.23 \mathrm{~g}$ の無水クロム酸を公温で徐々に添加した。約 8 時間かきま ぜたのち, 口過, $100 \mathrm{cc}$ 蒸留水で 3 回著沸したのち,エタノール, エーテルで洗浄, 减在下で乾燥した。黑褐色粉末 $1.7 \mathrm{~g}$ を得た。

本研究を行なうにあたり, 導電性の測定に関しては松下電工株 式会社滝内 唆氏に, 常磁性の測定では大阪府立放射線中央研究 所大过吉男氏に御援助を睗わった。こてに厚く謝意觉表する。 (1962 年 4 月, 日本化学会第 15 年会典演) 